\title{
Analysis of Ground Movement during Large-Scale Pipe Roof Installation and Artificial Ground Freezing of Gongbei Tunnel
}

\author{
Xiao-qi Zhou $\mathbb{D}^{1},{ }^{1}$ Jian-li Pan $\left(\mathbb{D},{ }^{2}\right.$ Yang Liu $(\mathbb{D}),{ }^{1}$ and Cai-cheng Yu ${ }^{3}{ }^{3}$ \\ ${ }^{1}$ School of Rail Transportation, Soochow University, Soochow 215131, China \\ ${ }^{2}$ China Railway 18 Bureau Group Co., Ltd., Tianjin 300350, China \\ ${ }^{3}$ JSTI Group, Nanjing 210000, China \\ Correspondence should be addressed to Xiao-qi Zhou; 1642403003@stu.suda.edu.cn
}

Received 6 July 2020; Accepted 27 July 2021; Published 9 August 2021

Academic Editor: Andreas Lampropoulos

Copyright ( $\odot 2021$ Xiao-qi Zhou et al. This is an open access article distributed under the Creative Commons Attribution License, which permits unrestricted use, distribution, and reproduction in any medium, provided the original work is properly cited.

\begin{abstract}
This paper analyzes the vertical ground movement during large-scale pipe roof installation and artificial ground freezing of Gongbei tunnel of the Hong Kong-Zhuhai-Macau bridge project. The transverse ground settlement during pipe roof installation is analyzed. The ground loss volume ratio and settlement trough width coefficient during pipe jacking are estimated based on the field measurement of ground settlement. The interaction of pipes during multiple jacking is investigated. The effect of frost heave control by pregrouting, limiting frozen soil thickness, and combination of the two methods is evaluated. The analysis shows that the ground settlement during pipe roof installation by jacking 37 pieces of $1620 \mathrm{~mm}$ steel pipes is relatively small with a maximum value of $2.2 \mathrm{~cm}$. The reinforcement to ground provided by the fore-jacked pipes reduces the ground loss volume ratio and, consequently, the ground settlement during the follow-up pipe jacking. The artificial ground freezing generates a relatively large ground heave with a maximum value of $7.8 \mathrm{~cm}$. Pregrouting plays a critical role in the frost heave control by reducing the heave by about $33 \%$. Limiting the frozen soil thickness by heating pipes serves as an effective supplement to frost heave control by reducing the heave by about $9 \%$. The combination of the two measures reduces the ground heave by about $42 \%$. Findings from this paper provide valuable reference to the tunnel construction using pipe roof and artificial ground freezing as presupport.
\end{abstract}

\section{Introduction}

With the advancement of tunnelling technique and increasing traffic demand, more and more large cross-section tunnels have been built in recent years. The International Tunneling Association (ITA) defines the large cross-section tunnels with an excavation area larger than $100 \mathrm{~m}^{2}$. Many tunnels with an excavation area larger than $200 \mathrm{~m}^{2}$ have been built, for example, the $336.8 \mathrm{~m}^{2}$ Gongbei tunnel in China [1], the $225 \mathrm{~m}^{2}$ Katabira tunnel in Japan [2], and the $252 \mathrm{~m}^{2}$ channel tunnel in Europe [3]. Ground movement control creates an engineering challenge during the excavation of large cross-section tunnels, especially for the shallowly buried ones in poor ground, such as soft clay/silt or loosely saturated sand. Previous construction experience indicates that the conventional sequential excavation supplemented with ground improvement, such as pregrouting, is difficult to excavate tunnels with the crosssectional area larger than $200 \mathrm{~m}^{2}$ in poor ground. Strong presupport is required to excavate such tunnels. The recently built Gongbei tunnel of the Hong Kong-ZhuhaiMacau bridge project has an excavation cross-sectional area of $336.8 \mathrm{~m}^{2}$ and burial depth of 4 to $5 \mathrm{~m}$ in interlayers of saturated clay/silt/sand. It applied a large-scale pipe roof in combination of artificial ground freezing as presupport. The pipe roof, composed of 36 pieces of $1620 \mathrm{~mm}$ diameter, $255 \mathrm{~m}$ length steel pipes, is designed to support the Earth load, while the artificial ground freezing is designed to seal the pipe roof to prevent water infiltration. Under such a strong presupport, the excavation induced ground movement is the minimum. However, large ground movement may occur during the installation of the pipe roof and artificial ground freezing, and the ground movement needs to be assessed. 
The pipe roof is installed through microtunnelling which generates ground movement. The ground settlement can be estimated by empirical, analytical, and numerical methods verified by field measurements or laboratory tests. The empirical methods provide a fast estimation of the ground movement and are widely used in engineering practice. The empirical equations assume that the transverse ground settlement follows a quasi-normal distribution, defined by the maximum settlement and the width coefficient of settlement trough [4]. The maximum settlement is characterized by the ground loss volume $V_{s}$, typically estimated using the ground loss volume ratio $(\eta)$. The $\eta$ value is impacted by mainly factors such as the machine type, ground condition, quality of compensation grouting, and local construction experience [5-11] and is reported in many publications. For example, O'Reilly and New early reported that the $\eta$ value ranges from $0.5-2.5 \%$ for cohesive soils and $2.0-10.0 \%$ for cohesionless soils in England [9]. Zhu and Li recently reported that the $\eta$ value of cohesive and cohesionless soils is about $1.10 \%$ and $1.18 \%$, respectively, based on summarization of the data from 20 regions in China [11]. The settlement trough width coefficient $i$ is related to ground condition, tunnel diameter, tunnel burial depth, etc. [12-14]. Different equations were proposed for the characterization of the width coefficient $i[9,15,16]$. For example, Burland et al. reported that the normalized width coefficient $k=i / z$, where $z$ is the tunnel burial depth from ground surface to tunnel centre, ranges from 0.2 to 0.3 for cohesionless soil, 0.4 to 0.5 for hard clay, and as high as 0.7 for silty clay based on the local experience in London [16]. Although the ground settlement induced by tunnelling is widely studied, the research is mostly focused on single- or double-line parallel tunnelling. Very limited study is found on the ground settlement during multiple parallel tunnelling as used for the pipe roof installation.

Frost heave control is a critical issue during artificial ground freezing. The frost heave mainly consists of two components, the in situ phase change one and the segregation one [17]. Between them, the segregation frost heave is the major one. The in situ phase change frost heave is caused by the icing of the pore water in the original soil, and the segregation frost heave is caused by the icing of pore water migrated from surrounding soils. The soil freezing is a complex hydrothermal-coupling process. The amount of segregation frost heave mainly depends on the change of temperature field and the rate of water migration. Controlling the temperature field and inhibiting the water migration are two major aspects of frost heave control [18]. Lai et al. analyzed the influence of temperature gradients on the frost heave of saturated soils. After freezing $90 \mathrm{~h}$, the frost heave caused by the temperature gradient of $0.65^{\circ} \mathrm{C} / \mathrm{cm}$ is 1.97 times of that caused by temperature gradient of $0.31^{\circ} \mathrm{C} /$ $\mathrm{cm}$ [19]. Zhang et al. analyzed the frost heave of soils with high permeability in cold regions and showed that controlling the temperature field only is difficult to control the frost heave in high permeable soils. To control the segregation frost heave, it has to reduce the permeability of the soil to inhibit the water migration. Pregrouting can reduce the soil permeability effectively and is widely used to control frost heave [20]. Hu reported that when the permeability of the soil decreases from $1.7 \times 10^{-6}$ to $6 \times 10^{-7} \mathrm{~cm} / \mathrm{s}$, the frost heave ratio reduces from $4.5 \%$ to $2 \%$ [21]. The previous studies mainly focused on the frost method, such as pregrouting or controlling temperature field, is usually applied to control the frost heave. The combination of multiple control methods is rarely applied in engineering practice.

The successful construction of the Gongbei tunnel provides valuable field measurement data. This paper investigates the vertical ground deformation during the installation of large-scale pipe roof and artificial ground freezing using Gongbei tunnel as a case project. Following the Introduction, Section 2 of the paper provides a brief description of the Gongbei tunnel. Section 3 analyzes the ground settlement and pipe interaction during multiple parallel jacking. Section 4 investigates the effect of three frost heave control methods, including pregrouting, limiting frozen soil thickness using heating pipes, and combination of the two methods. Section 5 discusses the total vertical ground deformation during pipe roof installation and artificial ground freezing. At the end, the conclusions are made in Section 6.

\section{Project Description}

2.1. General Description. The Gongbei tunnel is one of the most technically challenging components of the Hong Kong-Zhuhai-Macau bridge project. It is located beneath the Gongbei customer port operated by the Macau special administrative region (SAR) and Zhuhai city in southeast China. It has a length of $255 \mathrm{~m}$ along transitional and circular curves with a curvature ranging from 886 to $906 \mathrm{~m}$, as shown in Figure 1. It is a two-way, three-lane in each direction roadway tunnel with a cross-sectional area of $336.8 \mathrm{~m}^{2}$ and burial depth of 4 to $5 \mathrm{~m}$. Figure 2 shows the tunnel cross section and subsurface conditions. There are a variety of buildings, utilities, and piles adjacent to the excavation. The closest distance between the adjacent piles and excavation boundary is about $1.6 \mathrm{~m}$. The tunnel is mainly buried in saturated soft silt and clay with interlayers of fine sands. The subsurface strata consist of miscellaneous fill (stratum (1), soft organic clay and silt (stratum (3)-1), fine to coarse sand (stratum (3)-3), sandy clay and silt (stratum (4)-3), fine sand (stratum (5)-2), fine to coarse sand (stratum (6)-2), and silty clay (7)-1). The groundwater table ranges between El. 1 and El. 4 .

2.2. Pipe Roof Design. The Gongbei tunnel was excavated using the conventional method with a pipe roof in combination with artificial ground freezing as presupport. The pipe roof was designed to support the Earth loads, and the artificial ground freezing was designed to seal the pipe roof to avoid water infiltration between pipes. The pipe roof consists of 36 steel pipes with a diameter of $1620 \mathrm{~mm}$ and length of $255 \mathrm{~m}$. Besides the 36 roof pipes, one testing pipe ( $0^{\#}$ pipe) was designed adjacent to $5^{\#}$ pipe, as shown in Figure 2. These two pipes were installed first to test the jacking parameters. The wall thickness of the steel pipes is 


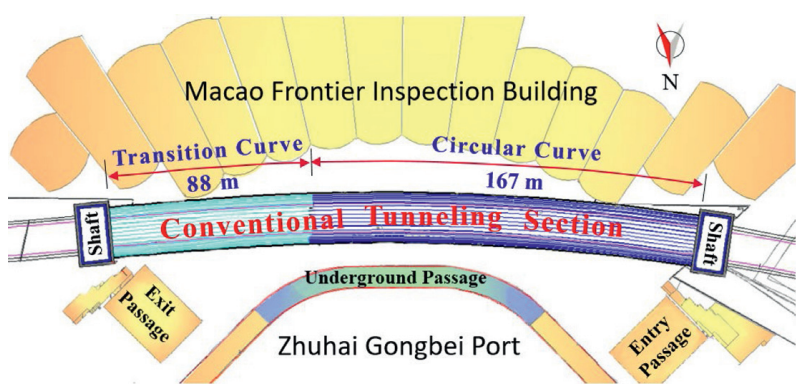

FIgure 1: Plane view of Gongbei tunnel.

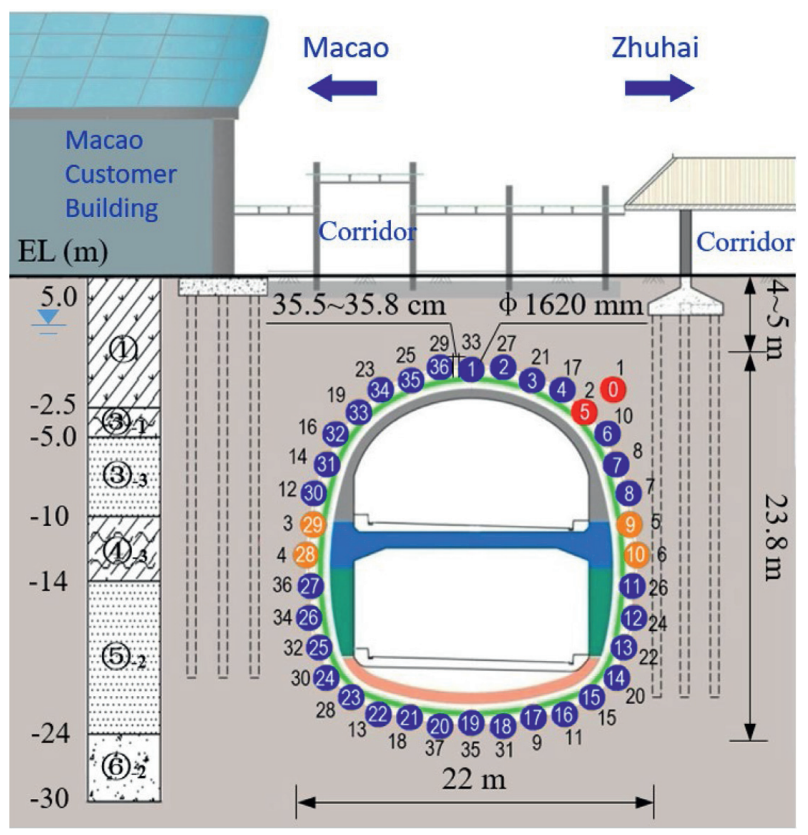

Figure 2: Profile view of Gongbei tunnel.

$20 \mathrm{~mm}$ for the lower 19 pipes and $24 \mathrm{~mm}$ for the upper 18 pipes. The net spacing between adjacent pipes is $35.5-35.8 \mathrm{~cm}$. The roof pipes were installed through microtunneling using slurry shield machines. Four $1667 \mathrm{~mm}$ diameter AVN1200TC machines purchased from Herrenk Necht in Germany were used to jack the pipes section-bysection with a sectional length of $4 \mathrm{~m}$ from a vertical shaft at one end of the tunnel. The pipes were received at a vertical shaft on the other end of the tunnel.

2.3. Artificial Ground Freezing Design. Figures $3-5$ show the design of the artificial ground freezing. Figure 3 shows that the freezing pipes were installed inside the steel roof pipes. The freezing system include three different pipes which are the circular freezing pipes, irregular shape freezing pipes, and circular heating pipes. Two circular freezing pipes were installed at the sidewall of the odd number roof pipes, which were filled with lightly expansive concrete, to circulate cold brine. A circular heating pipe was installed at the crown of the odd number roof pipes to circulate hot brine with temperature of $5-10^{\circ} \mathrm{C}$ to limit the thickness of frozen soil to avoid the excessive frost heave. Two irregular shape freezing

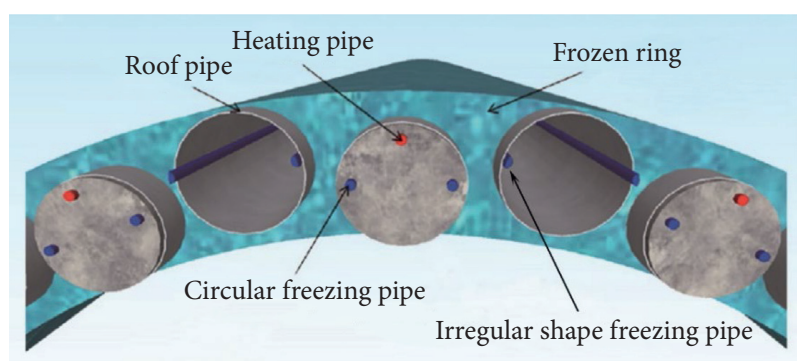

Figure 3: Arrangements of freezing pipes.

pipes were installed at the sidewall of the even number pipes to circulate cold brine. The even number of roof pipes were filled with concrete after the excavation was completed, and the permanent liner was installed. Figure 4 shows that, along tunnel longitudinal length, three independent freezing loops were designed with a round length of about $85 \mathrm{~m}$. Figure 5 shows that the tunnel cross section was divided into 5 freezing zones, $A, B 1, B 2, B 3$, and $C$. The frozen ring thickness of zones $A, B 1$, and $B 2$ was designed to be within 2 to $2.3 \mathrm{~m}$ and 2 to $2.6 \mathrm{~m}$ for zones $B 3$ and $C$.

To further control frost heave, the soils around the pipe roof were pregrouted to reduce the permeability. The thickness of soil grouting was designed as 2.5 to $3 \mathrm{~m}$. The pregrout was conducted through the predrilled holes in the roof pipes. Figure 6 shows the arrangement of the grouting holes. Within each $4 \mathrm{~m}$ length pipe section, 28 grouting holes were predrilled along 4 equally spaced rolls. Each roll contains 7 holes distributed along the circumferential length of the pipe. The grouting pipes have a diameter of $32 \mathrm{~mm}$ and length of $1.5 \mathrm{~m}$. The grout was made of microfine cement and bentonite with a water-cement ratio $(W / C)$ of $1: 1$ and bentonite dosage of $3 \%$. The grouting pressure of the upper, middle, and lower parts of the pipe roof was controlled at $0.05-0.15 \mathrm{MPa}, 0.15-0.3 \mathrm{MPa}$, and $0.3-0.5 \mathrm{MPa}$, respectively. The grouting speed was controlled to $5-25 \mathrm{~L} / \mathrm{min}$ at the early stage, $5-15 \mathrm{~L} / \mathrm{min}$ at the middle stage, and less than $5 \mathrm{~L} / \mathrm{min}$ at the end stage.

\section{Ground Settlement Induced by Pipe Jacking}

The construction of the Gongbei tunnel was started in Oct 2012 and completed in Aug 2018. The successful construction of the Gongbei tunnel provides valuable field measurement data on analysing the ground movement during the installation of the large-scale pipe roof and artificial ground freezing. To analyze the ground settlement induced by multiple parallel pipe jacking, the critical parameters, including ground loss volume ratio $\eta$ and the settlement trough width coefficient $i$, are derived based on the field measurement. The pipe interaction during multiple parallel jacking is analyzed using analytical and numerical methods.

3.1. Field Measurement Analysis. The jacking order of the pipes is labeled outside the pipes, as shown in Figure 2. The jacking process was divided into three stages, including stage 


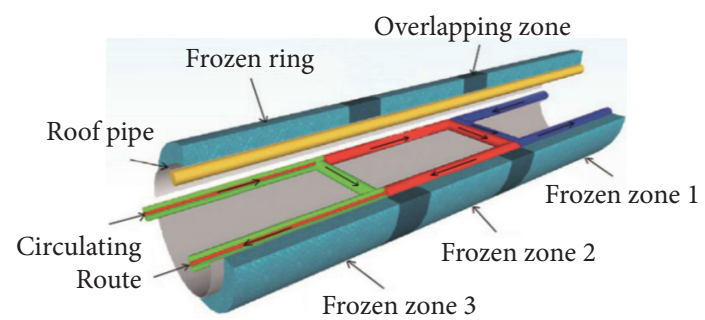

FIGURE 4: Longitudinal sections of artificial ground freezing.

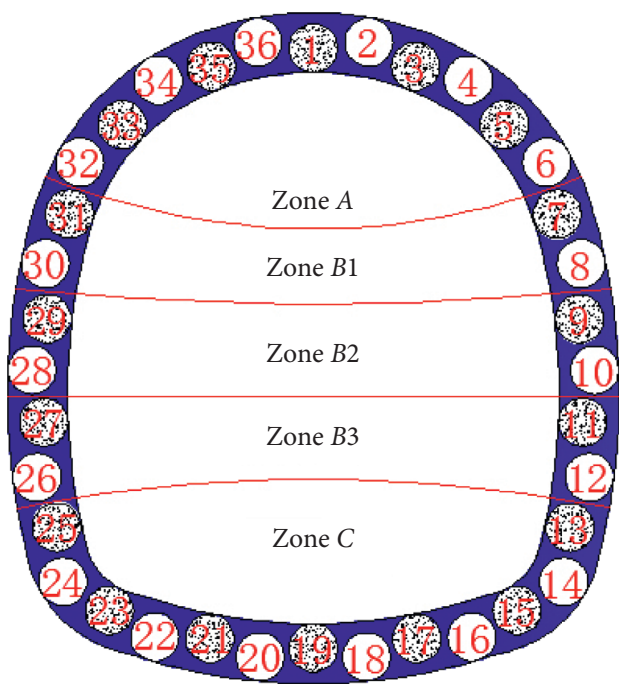

FIGURE 5: Zonation of artificial ground freezing within tunnel cross section.

I $\left(0^{\#}\right.$ and $5^{\#}$ testing pipes $)$, stage II $\left(29^{\#}, 28^{\#}, 9^{\#}\right.$, and $10^{\#}$ pipes), and stage III (the remaining pipes). During pipe jacking, the settlement at the ground surface was monitored. Figure 7 shows the layout of the monitoring points, including 389 points within 24 cross sections which were set along the tunnel alignment at an interval of $10 \mathrm{~m}$. In each cross section, the ground settlement was measured with $2 \mathrm{~m}$ interval within tunnel excavation boundary and with $4,6,8$, and $10 \mathrm{~m}$ interval outside the excavation boundary. To avoid the potential impact of the launching and receiving shafts, three monitoring sections CJ5, CJ15, and CJ21 in the middle of the tunnel alignment are selected for data analysis.

The cumulative ground settlement at the three cross sections during the installation of the 37 pipes is shown in Figure 8 . The positive direction of the $x$-axis represents north direction. During the stage I jacking, the ground settlement caused by jacking $0^{\#}$ and $5^{\#}$ pipe was about $2.7 \mathrm{~mm}$ and $2.2 \mathrm{~mm}$, respectively, and the cumulative settlement was about $5 \mathrm{~mm}$. During stage II, the installation of the $9^{\#}, 10^{\#}$, $28^{\#}$, and $29^{\#}$ pipe caused a cumulative increase of ground settlement of about $2 \mathrm{~mm}$. During stage III, the maximum settlement first accumulated on the north side of the tunnel centerline and gradually approached to the tunnel centerline as the jacking process continued. At the end of jacking the 37 pipes, the ground settlement curve at each cross section was in an approximate normal distribution along horizontal direction with the maximum value occurring above tunnel centerline, and the inflection point was located at the position with a horizontal distance of about $12 \mathrm{~m}$ from the tunnel centerline. The maximum ground settlement at the three sections ranged from 21.4 to $22.2 \mathrm{~mm}$.

The ground settlement caused by single pipe jacking is calculated as the difference between the cumulative ground settlement at the end of the pipe jacking and that of the fore pipe jacking. Based on the field measurement data at the three sections, the settlement curve during each pipe jacking was fitted with Peck's equations:

$$
\begin{aligned}
& S(x)=S_{\max } \exp \left(-\frac{x^{2}}{2 i^{2}}\right), \\
& S_{\max }=\frac{V_{s}}{\sqrt{2 \pi i}},
\end{aligned}
$$

where $S(x)$ is the ground settlement at a distance $x$ from the tunnel axis, $S_{\max }$ is the maximum ground settlement above the tunnel axis, $V_{s}=\eta \pi R^{2}$ is unit ground loss, in which $\eta$ is the ground loss volume ratio, and $i$ is the ground settlement trough width coefficient. $i$ and $S_{\max }$ obtained by curve fitting are substituted into equation (2) to back calculate the corresponding $V_{s}$. Then, the ground loss ratio $\eta$ of single pipe jacking is derived according to $V_{s}=\eta \pi R^{2}$. The width parameter $k$ is calculated by

$$
k=\frac{i}{z}
$$

where $z$ is the burial depth of the roof pipe. Figure 9 presents the ground settlement trough width coefficient $i$, width parameter $k$, ground loss volume ratio $\eta$, and maximum ground settlement $S_{\max }$ during jacking each pipe. The settlement trough width coefficient $i$ ranges from $3.4 \mathrm{~m}$ to $15.4 \mathrm{~m}$. The width parameter $k$ ranges from 0.3 to 0.87 and decreases with the increase in pipe burial depth. The maximum ground settlement $S_{\max }$ ranges from 0.2 to $2.7 \mathrm{~mm}$ and also decreases with increasing pipe burial depth. Figure 9 (d) shows that the $\eta$ value ranges from $0.3 \%$ to $1.5 \%$. The $\eta$ value of $0^{\#}$ pipe jacking of three sections is about $1.5 \%$. The average $\eta$ value for the 37 pipes was about $0.8 \%$.

Based on the analysis, the ground settlement trough width coefficient $i$ is closely related to pipe burial depth, which is consistent with the finding from literature $[11,22]$. In Figure 10, the relationship between the width coefficient $i$ of each pipe and the pipe burial depth is plotted and is compared with empirical relationships. The width coefficient curve is generally in accordance with the empirical relationships. When the pipe burial depth is less than $15 \mathrm{~m}$, the relationship is close to the Liu and\& Hou's [23] relationship. It approaches to the O'Reilly and New's relationship when the pipe burial depth is deeper than $25 \mathrm{~m}$. The regression function is $i=0.35 z+2.72$, and the correlation coefficient $R^{2}$ is 0.86 .

3.2. Pipe Interaction Analysis. During the installation of pipe roof, the fore-jacked pipes have a reinforcement effect to the ground. The reinforcement increases the stiffness of the ground and reduces the ground loss during consequent 

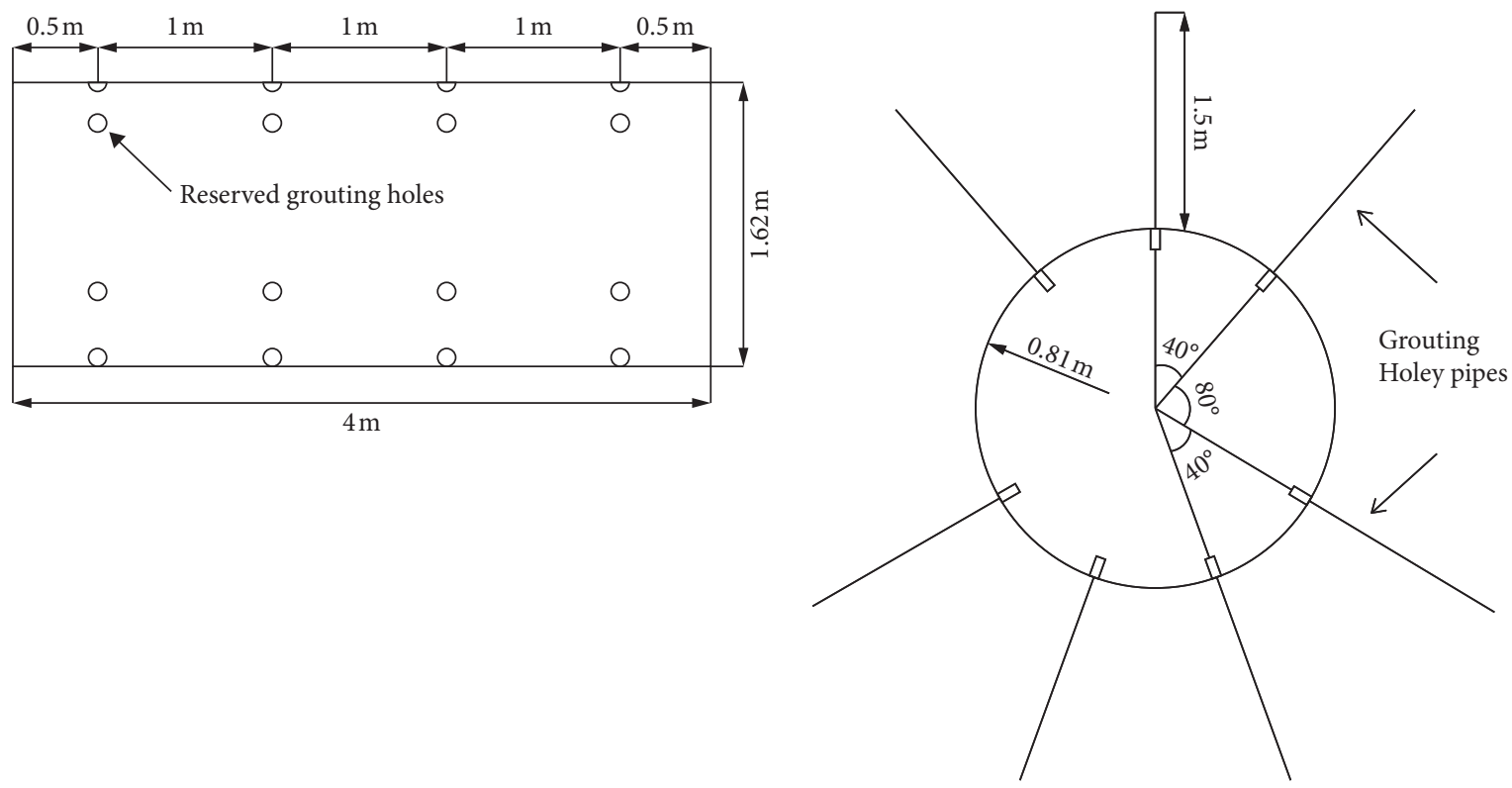

(a)

(b)

FIGURE 6: Design of pregrouting around pipe roof. (a) Layout of predrilled grouting holes. (b) Layout of holey grouting pipes.

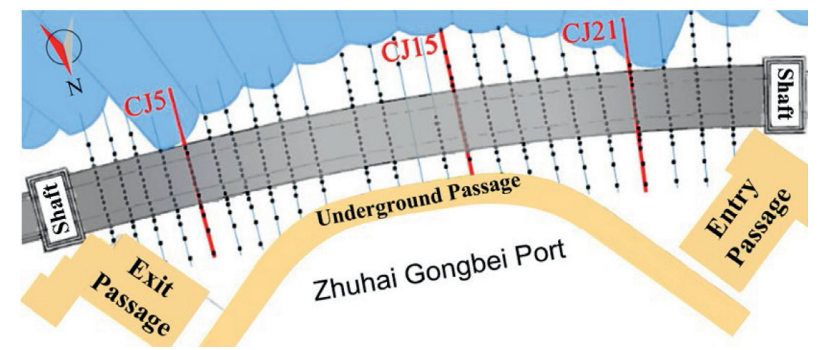

FIGURE 7: Layout of ground deformation monitoring points.

jacking $[24,25]$. To investigate the interaction of pipes during multiple parallel jacking, the ground settlement is estimated using analytical and numerical analysis, and the analysis results are compared with the field measurement.

During analytical analysis, Peck's empirical equation is applied to single pipe jacking. The ground loss volume ratio is assumed as $1.5 \%$ which is obtained from the back calculation of settlement during jacking the first $\left(0^{\#}\right)$ pipe where no pipe interaction exists, and the width coefficient $i$ is calculated using the regression $i=0.35 z+2.72$. The cumulative ground settlement is obtained from superposition of the settlement of each pipe. As such, no pipe interaction is considered in the analytical analysis. The numerical analysis is conducted using a two-dimensional plane stain model by finite element (FE) software Plaxis 2D. The ground loss volume ratio is assumed as $1.5 \%$ for all the pipes. The model was built with a width of $80 \mathrm{~m}$ and a depth of $38.5 \mathrm{~m}$. As shown in Figure 11(a), the 15-node triangular elements are adopted for mesh generation, and there are total of 2931 units and 24747 nodes in the model. The steel pipes are simulated using plate elements with an elastic modulus of $210 \mathrm{GPa}$ and Poisson's ratio of 0.2 . The ground loss is simulated by reducing the diameter of the pipes, and the radial contraction rate is set to $1.5 \%$. The small-strain soil hardening model (Hss) was applied to the soils. The shear strength parameters of the soil were determined based on the tri-axial consolidated drainage tests. The stiffness modulus is converted according to the Plaxis manual: $E_{\text {oed }}=E_{\mathrm{s}}$, $E_{50}=E_{\text {oed }}, E_{\text {ur }}=4 E_{\text {oed }}$, and $G_{0}=4 E_{\text {ur }}$. Parameters used in numerical simulation are detailed in Tables 1-3. According to the jacking order, as shown in Figure 2, the pipe roof installation was simulated as follows: stress initialization $\longrightarrow$ excavation and support of $0^{\#}$ pipe $\longrightarrow$ excavation and support of $5^{\#}$ pipe $\longrightarrow \cdots \cdots$. excavation and support of $20^{\#}$ pipe.

Figures 11(b)-11(d) show the vertical ground deformation at the end of the stage $\mathrm{I}\left(0^{\#}\right.$ and $5^{\#}$ pipe jacking $)$, stage II $\left(9^{\#}, 10^{\#}, 28^{\#}\right.$, and $29^{\#}$ pipe jacking), and stage III (remaining pipes jacking). During stage I, the settlement is distributed symmetrically around $0^{\#}$ and $5^{\#}$ pipes, and the maximum settlement occurs directly above them. With the pipe jacking continuing during stage II, there is a further increase in the ground settlement above $0^{\#}$ and $5^{\#}$ roof pipes. The soil deformation caused by $9^{\#}$ and $10^{\#}$ pipe jacking is smaller than that caused by $28^{\#}$ and $29^{\#}$ pipe jacking in spite of the same burial depth. That is mainly because the 

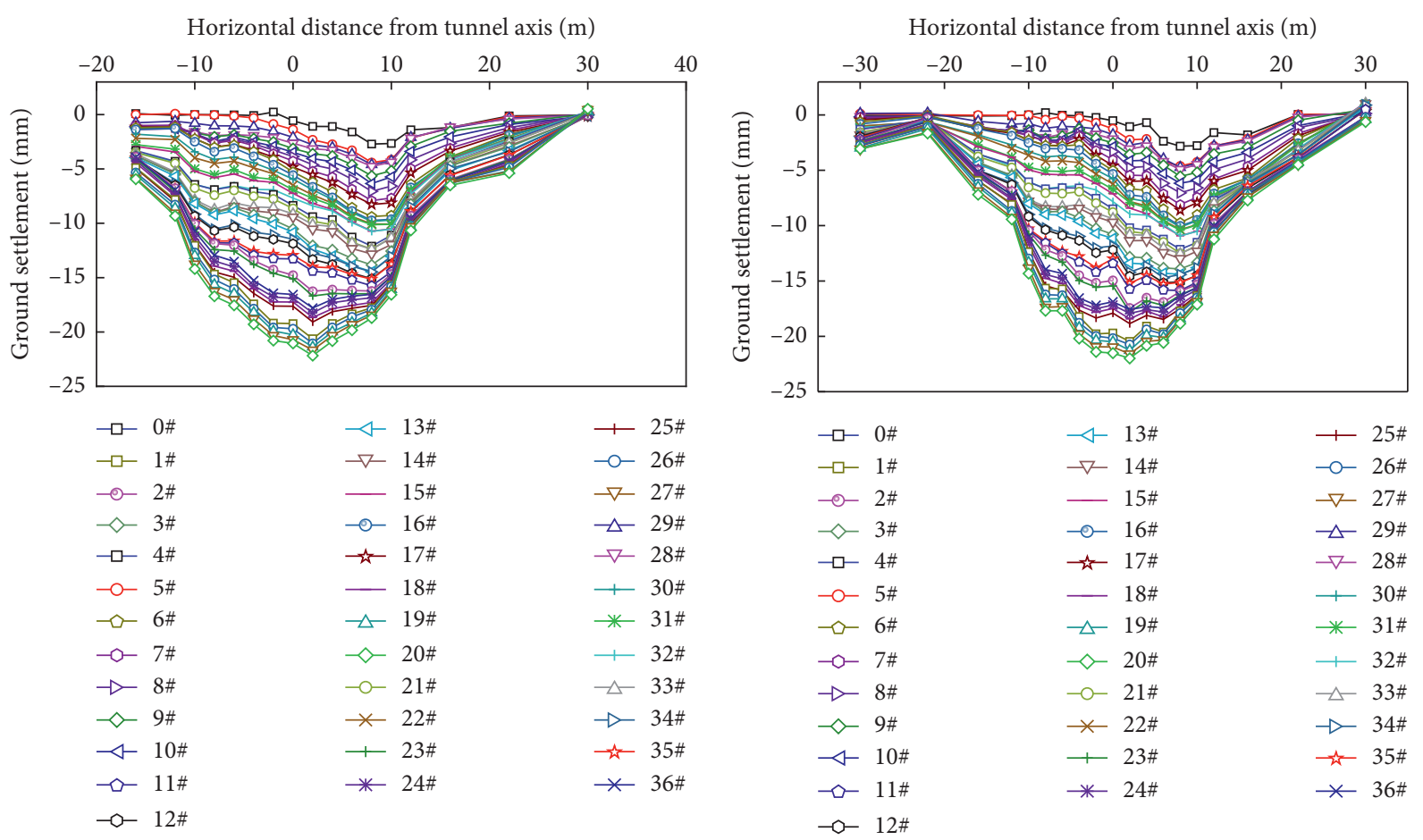

(a)

(b)

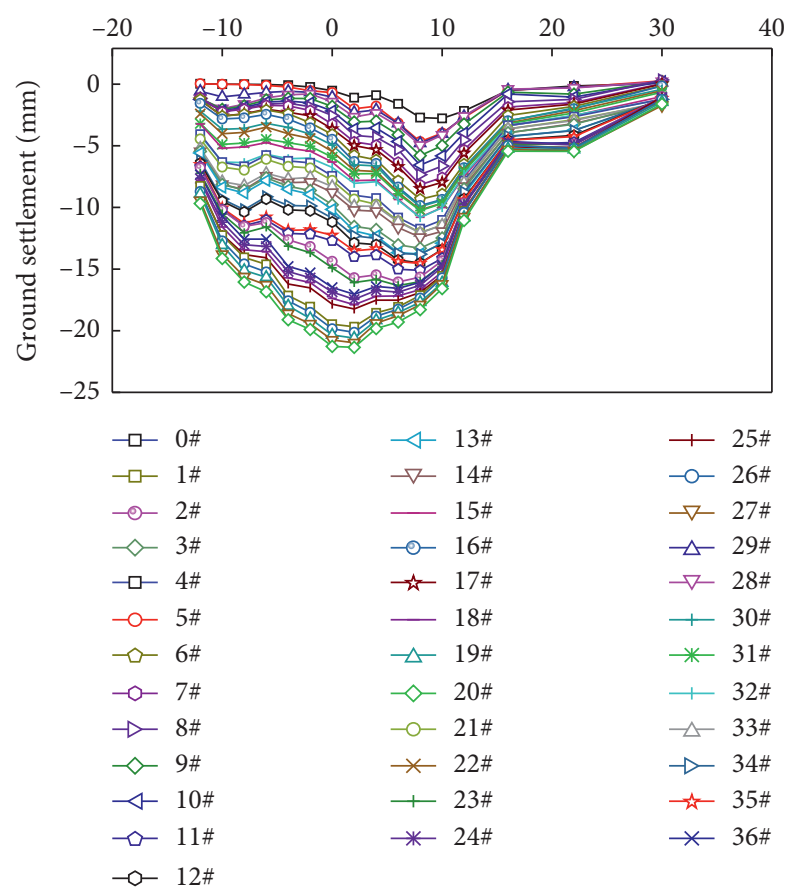

(c)

Figure 8: Transverse ground settlement at the end of each pipe jacking. (a) Section CJ5. (b) Section CJ15. (c) Section CJ21.

fore-jacked $0^{\#}$ and $5^{\#}$ roof pipes provide a reinforcement effect on soil. The maximum ground settlement is still above $0^{\#}$ and $5^{\#}$ roof pipes at the end of stage II. During stage III, the maximum ground settlement at the end of all 37 pipes jacking is above the centerline of the tunnel, and the ground settlement decreases with the increasing horizontal distance from the axis.

Figure 12 shows the cumulative ground settlement at the end of three stages of pipe jacking. Since the ground settlement caused by single pipe jacking is calculated and 


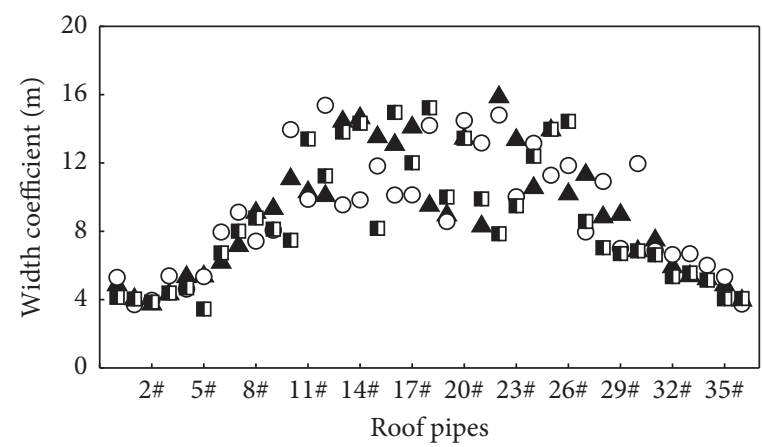

( CJ5

O CJ15

- CJ21

(a)

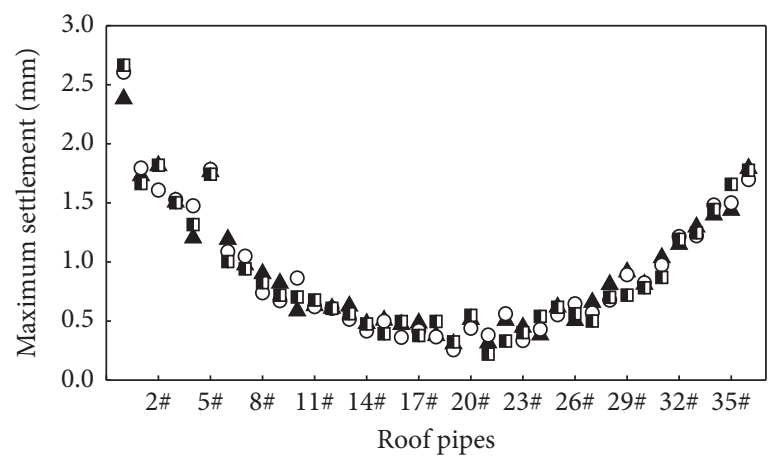

^ CJ5

O CJ15

- CJ21

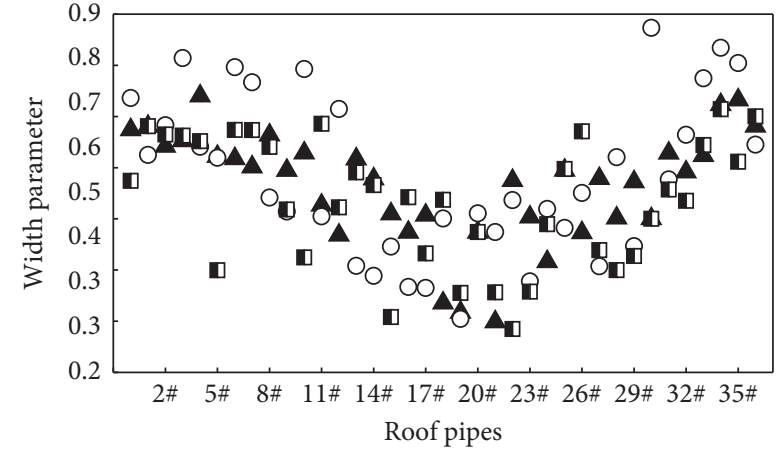

A CJ5

O CJ15

(1 C)21

(b)

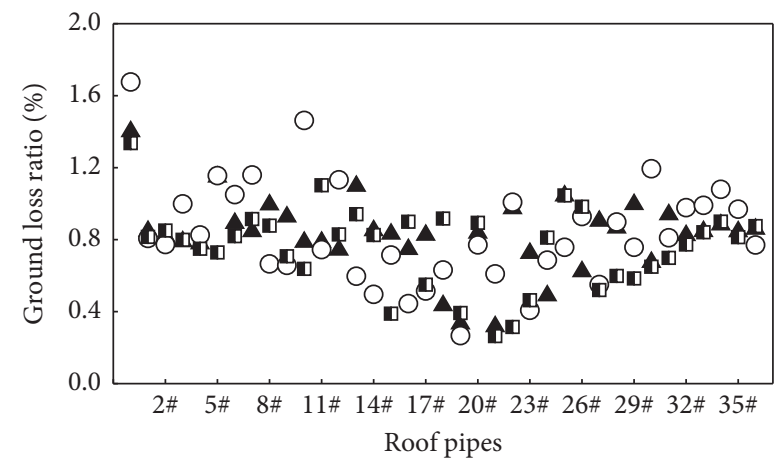

$\Delta$ CJ5

O CJ15

I CJ21

(c)

(d)

Figure 9: Calculated values of $i, k, s_{\max }$, and $\eta$ at the end of each pipe jacking. (a) Settlement trough width coefficient $i$. (b) Settlement trough width parameter $k$. (c) Maximum settlement $S_{\max }$ (d) Ground loss ratio $\eta$.

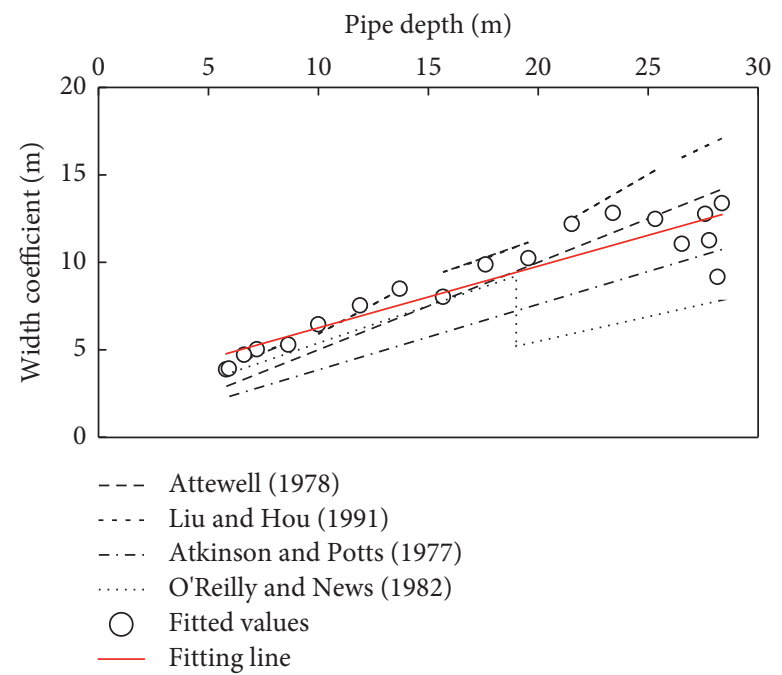

FIGURE 10: Relationship between settlement trough wide coefficient and pipe depth.

simulated with the same ground loss volume ratio of $1.5 \%$, the calculated values and simulated values of each stage represent the cumulative ground settlement without pipe interaction. The measured values account for the effect of pipe interaction. Therefore, the pipe interaction can be analyzed by the comparison of the measured, simulated, and calculated ground settlement. Figure 12 shows that the simulation results are consistent with the calculation results. 


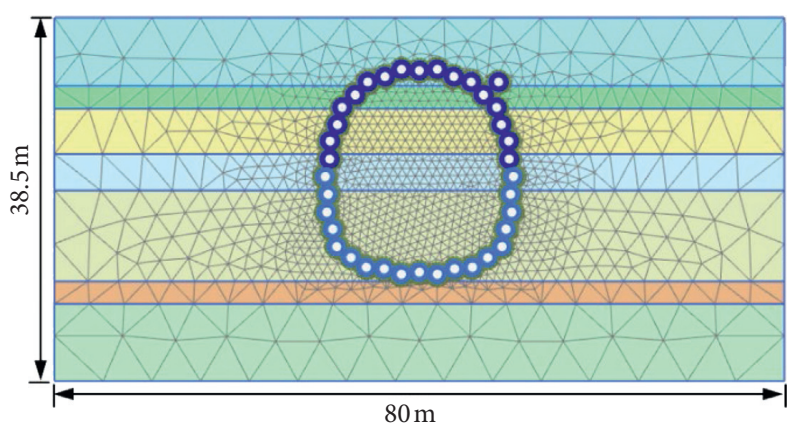

(a)

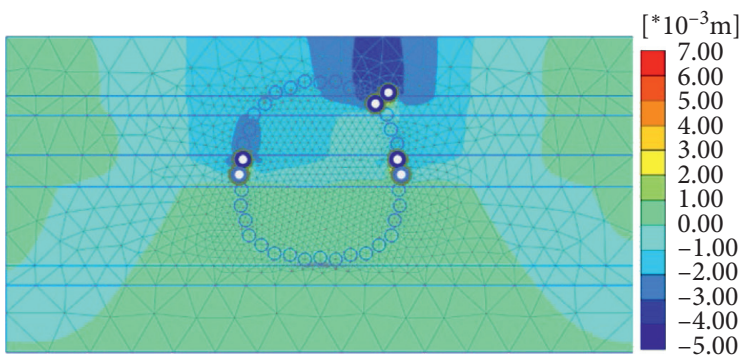

(c)

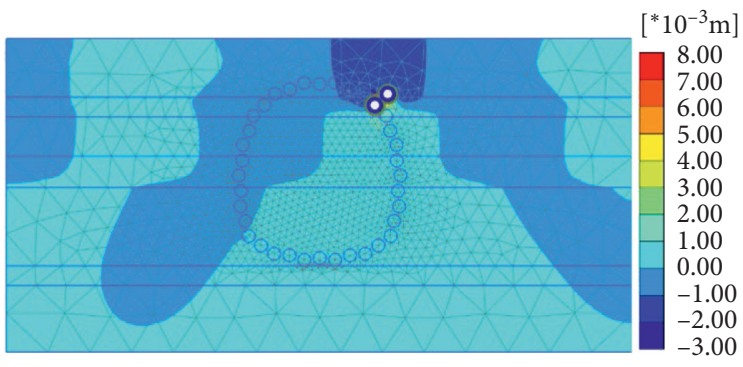

(b)

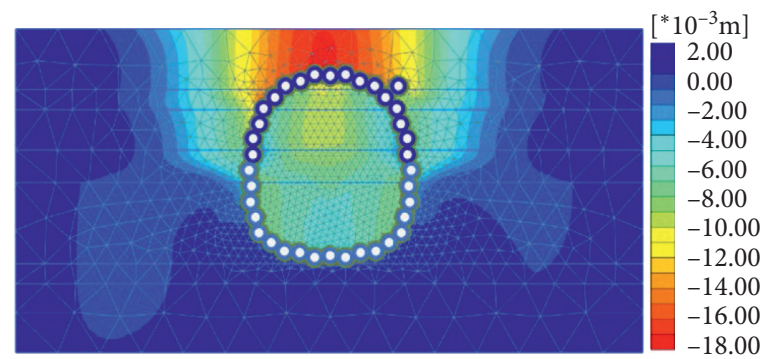

(d)

Figure 11: Pipe roof model and vertical ground deformation at the end of three stages. (a) Pipe roof model. (b) Stage I of pipe jacking. (c) Stage II of pipe jacking. (d) Stage III of pipe jacking.

TABle 1: Pipe parameters.

\begin{tabular}{lccrr}
\hline Material & Material type & EA $(\mathrm{kN} / \mathrm{m})$ & $\mathrm{EI}\left(\mathrm{kN} \cdot \mathrm{m}^{2} / \mathrm{m}\right)$ & \multicolumn{1}{c}{} \\
\hline Upper pipes & Elastic & 4200000 & 140 & 0.2 \\
Lower pipes & Elastic & 5040000 & 241.9 & 0.2 \\
\hline
\end{tabular}

TABLe 2: Physical and mechanical parameters of soil strata.

\begin{tabular}{|c|c|c|c|c|c|c|}
\hline \multirow{2}{*}{ Soil stratum } & \multirow{2}{*}{ Thickness $h(\mathrm{~m})$} & \multirow{2}{*}{ Unit weight $\gamma\left(\mathrm{kN} / \mathrm{m}^{3}\right)$} & \multicolumn{2}{|c|}{ CU-test } & \multicolumn{2}{|c|}{ CD-test } \\
\hline & & & $c(\mathrm{kPa})$ & $\varphi\left({ }^{\circ}\right)$ & $c^{\prime}(\mathrm{kPa})$ & $\varphi^{\prime}\left({ }^{\circ}\right)$ \\
\hline Fill & 7.5 & 18.5 & 3.0 & 25.0 & 0 & 29.0 \\
\hline Clay and silt (3)-1 & 2.5 & 15.4 & 6.0 & 13.0 & 2 & 25.0 \\
\hline Fine to coarse sand (3)-3 & 5.0 & 20.0 & 4.0 & 25.0 & 0 & 29.0 \\
\hline Sandy clay and silt (4)-3 & 4.0 & 17.9 & 11.4 & 6.5 & 3 & 27.0 \\
\hline Fine sand (5)-2 & 10.0 & 20.5 & 4.0 & 26.0 & 0 & 30.0 \\
\hline Fine to coarse sand (6)-2 & 2.5 & 19.5 & 2.0 & 30.0 & 0 & 32.0 \\
\hline Silty clay (7)-1 & 7.0 & 18.0 & 12.3 & 7.6 & 3 & 28.0 \\
\hline
\end{tabular}

Notes: CU denotes Consolidation Undrained; CD denotes Consolidation Drained.

TABLE 3: Material parameters of soil strata.

\begin{tabular}{|c|c|c|c|c|c|c|c|}
\hline \multirow{2}{*}{ Soil stratum } & \multirow{2}{*}{ Material model } & \multirow{2}{*}{ Drainage type } & \multicolumn{3}{|c|}{ Stiffness modulus } & \multicolumn{2}{|c|}{ Hss } \\
\hline & & & $E_{50}(\mathrm{MPa})$ & $E_{\text {oed }}(\mathrm{MPa})$ & $E_{\text {ur }}(\mathrm{MPa})$ & $\gamma_{0.7}$ & $G_{0}(\mathrm{MPa})$ \\
\hline Fill & Hss & Drained & 6 & 6 & 24 & $2 e-4$ & 96 \\
\hline Clay and silt (3)-1 & Hss & Drained & 2 & 2 & 8 & $2 e-4$ & 32 \\
\hline Fine to coarse sand (3)-3 & Hss & Drained & 10 & 10 & 40 & $2 e-4$ & 160 \\
\hline Sandy clay and silt (4)-3 & Hss & Drained & 3 & 3 & 12 & $2 e-4$ & 48 \\
\hline Fine sand (5)-2 & Hss & Drained & 13 & 13 & 52 & $2 e-4$ & 208 \\
\hline Fine to coarse sand (6)-2 & Hss & Drained & 15 & 15 & 60 & $2 e-4$ & 240 \\
\hline Silty clay (7)-1 & Hss & Drained & 5 & 5 & 20 & $2 e-4$ & 80 \\
\hline
\end{tabular}




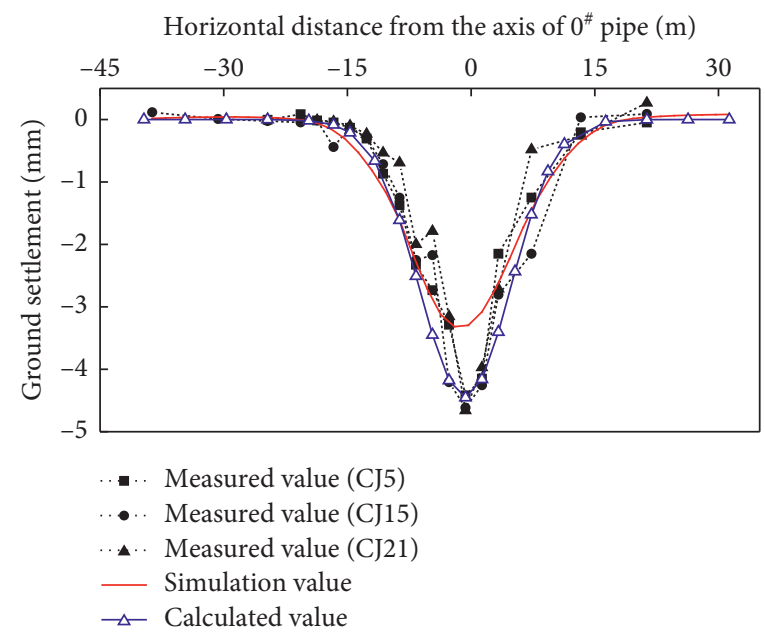

(a)

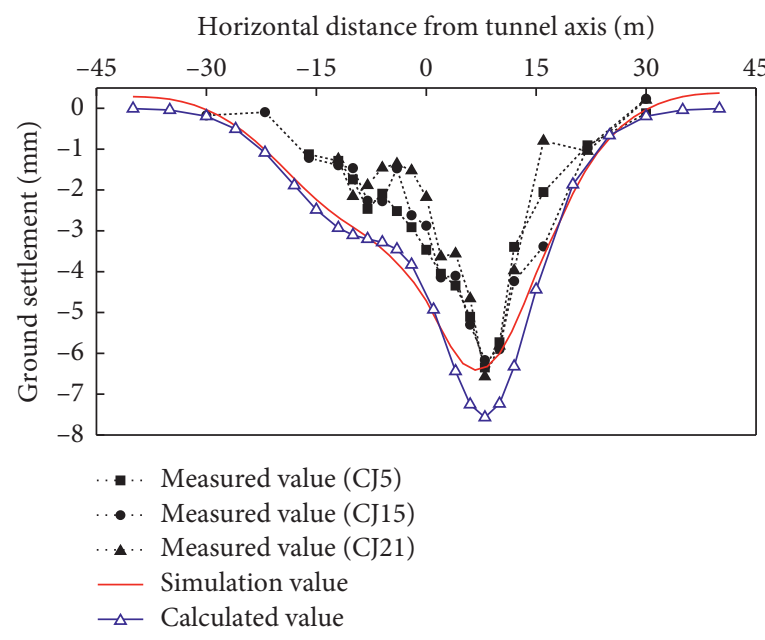

(b)

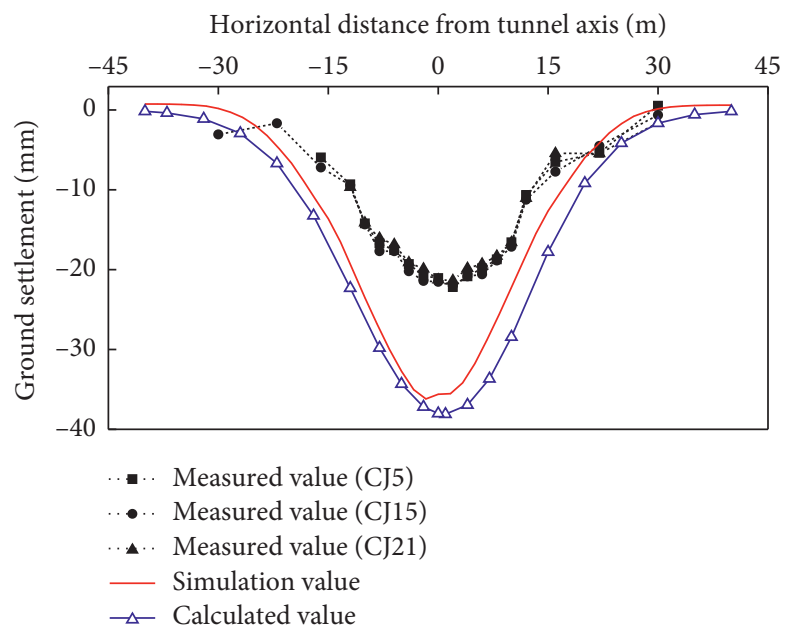

(c)

FIGURE 12: Ground cumulative settlement at the end of three stages of pipe jacking. (a) Stage I of pipe jacking. (b) Stage II of pipe jacking. (c) Stage III of pipe jacking.

During stage I, the calculated, simulated, and measured values generally match each other, and the pipe interaction is not obvious. During stage II, the calculated and simulated values are slightly larger than measured values. Considering that only few pipes are jacked in this stage, the reinforcement effect is not significant. At the end of stage III, the calculated and simulated values are twice of the measured values. It shows that the fore-jacked multiple pipes provide a reinforcement effect to the ground and limits the soil deformation. The maximum ground settlement decreases by around $16 \mathrm{~mm}$ due to the pipe interaction.

\section{Frost Heave Analysis}

The artificial ground freezing is designed to provide water tightness between adjacent pipes. The major issue related to the artificial ground freezing is the frost heave, which, if not well controlled, may damage the adjacent structures and utilities. The control of the frost heave consists of two aspects, limiting the thickness of the frozen soil to limit the in situ frost heave and reducing the water content and permeability of the soil by grouting to limit both the in situ and segregation frost heave.

4.1. Numerical Simulation. The frost heave was analyzed using finite element (FE) software COMSOL Multiphysics. Based on the elastic constitutive relation of soil skeleton, the COMSOL applies a thermal-coupling model to calculate the frost heave considering the ice-water phase transition, water migration in the soil, and variation of the soil temperature during the freeze-thaw process. The basic assumptions of the model include the following: (1) the soils are isotropic elastic materials; (2) ice-water phase transition occurs at $-5^{\circ} \mathrm{C}$; (3) the heat conduction follows Fourier's Law; (4) the water migration takes place in the form of liquid water only and is driven by the gradient of unfrozen water following Darcy's law; (5) the soil skeleton is a low-temperature expansion material, and the expansion coefficient is defined as the 


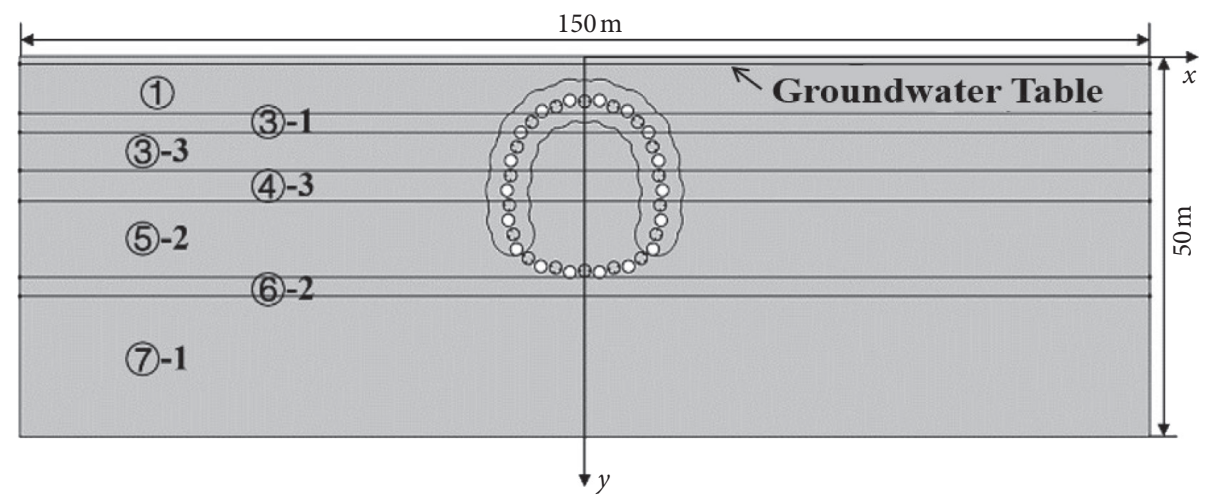

(a)

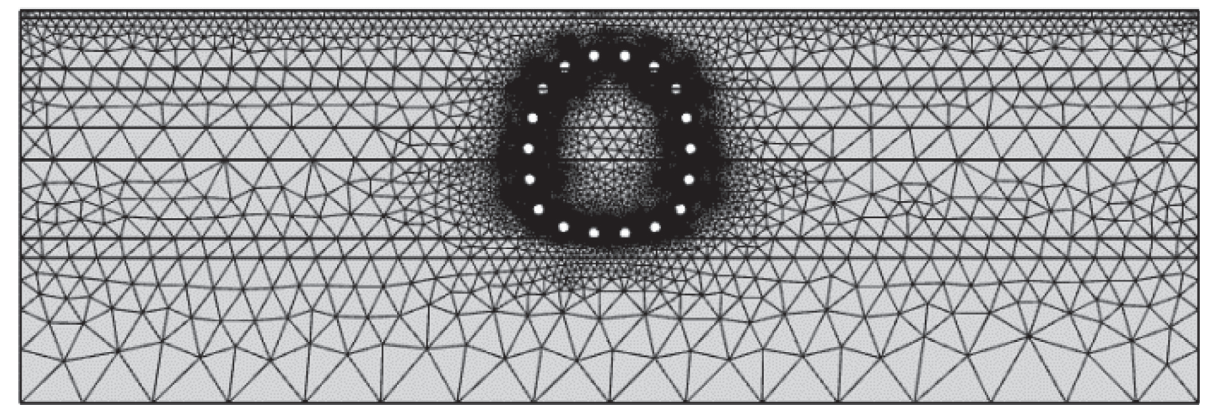

(b)

Figure 13: The finite element model of Gongbei tunnel. (a) The calculation model. (b) The mesh model.

equivalent expansion coefficient considering the interaction of soil skeleton, ice, and water.

A two-dimensional FE model of the tunnel cross section is established. The FM model is shown in Figure 13. The model size is set as $150 \times 50 \mathrm{~m}$ and is meshed freely by triangular elements. The minimum element size is set to $1 \mathrm{~cm}$. Total of 69954 elements are established with the average mesh quality of 0.92 . The subsurface strata consist of 7 layers. The groundwater table is set at $1 \mathrm{~m}$ below the ground surface. The mechanical properties of soils obtained from lab tests are listed in Table 4 . The thermo-physical properties of soils before and after grouting are listed in Table 5. The grouted soils were obtained through field samples. In total, 72 holes were drilled which account for $8 \%$ of 900 grouting holes. The density, water content, strength, and frost heave ratio of the samples were determined by laboratory testing. The on-site hydraulic test was conducted in the drill holes to determine the soil permeability after taking samples. The physico-mechanical parameters of soils before and after grouting are detailed in Table 4 . In general, the porosity of the soils decreases by approximately $13 \%$ from $0.26-0.67$ to $0.22-0.60$. The permeability coefficient decreases from $10^{-2}-10^{-7} \mathrm{~cm} / \mathrm{s}$ to $10^{-5}-10^{-7} \mathrm{~cm} / \mathrm{s}$. The elastic modulus increases by $118-1156 \%$ from $1.6-15.0 \mathrm{MPa}$ to $20.1-32.7 \mathrm{MPa}$ after grouting. According to the result of freezing tests, the specific heat capacity of soils decreases by around $5 \%$, and the frost heave ratio decreases by $12 \%$ from $3.82 \%-6.63 \%$ to $3.53 \%-5.46 \%$.

The ground surface temperature is set to $21^{\circ} \mathrm{C}$. The temperature of circular freezing pipes, irregular-shaped freezing pipes, heating pipes, and empty roof pipes are set to $-28^{\circ} \mathrm{C},-24^{\circ} \mathrm{C}, 8^{\circ} \mathrm{C}$, and $-10^{\circ} \mathrm{C}$, respectively. The soil temperature considering water migration is calculated by the coefficient differential equation PDE module. The ground deformation is calculated using the solid mechanics module.

4.2. Result Analysis. Four scenarios were simulated. They are without frost control measures, control scheme I: activating heating pipes, control scheme II: pregrouting, and control scheme III: the combination of pregrouting and activating heating pipes. Figure 14 shows the ground heave of four scenarios after freezing of 30, 50, and 70 days (d). The ground heave increases with the freezing time with the development of frozen soil. The maximum heave occurs above the tunnel centerline. The ground deformation curves of scheme I, II, and III are all below that without control measures. The three schemes are beneficial to frost heave control, and scheme III is most effective. After freezing for $70 \mathrm{~d}$, the maximum heave without control measures and with scheme I, II, and III control measures is $13.5,12.3,9.0$, and $7.8 \mathrm{~cm}$, respectively. The maximum ground heave decreases 9\% with scheme I, 33\% with scheme II, and $42 \%$ with scheme III. The decrease of maximum heave of scheme II and III is $4.5 \mathrm{~cm}$ and $5.8 \mathrm{~cm}$ respectively, which are 2.75 and 3.83 times of $1.2 \mathrm{~cm}$, and the decrease of heave of scheme I indicates that pregrouting plays a critical role in the frost heave control. This is because the pregrouting forms a grout-soil composite which has a lower permeability, thus hindering the water 
TABLE 4: Soil parameters before and after grouting.

\begin{tabular}{|c|c|c|c|c|c|c|c|c|c|c|c|}
\hline \multirow[t]{2}{*}{ Soil stratum } & \multirow[t]{2}{*}{ Thickness (m) } & \multicolumn{2}{|c|}{$\begin{array}{l}\text { Unit weight } \\
\left(\mathrm{kN} / \mathrm{m}^{3}\right)\end{array}$} & \multicolumn{2}{|c|}{ Porosity } & \multicolumn{2}{|c|}{ Permeability $(\mathrm{cm} / \mathrm{s})$} & \multicolumn{2}{|c|}{$\begin{array}{l}\text { Poisson } \\
\text { ratio }\end{array}$} & \multicolumn{2}{|c|}{$\begin{array}{c}\text { Water } \\
\text { content (\%) }\end{array}$} \\
\hline & & $\mathrm{B}$ & A & $\mathrm{B}$ & A & $\mathrm{B}$ & A & $\mathrm{B}$ & A & B & A \\
\hline Fill & 7.5 & 18.5 & 20.7 & 0.67 & 0.6 & $3.44 e-5$ & $1.72 e-5$ & 0.35 & 0.23 & 16.1 & 12.8 \\
\hline Clay and silt (3)-1 & 2.5 & 15.4 & 17.2 & 0.67 & 0.6 & $2.29 e-7$ & $1.14 e-7$ & 0.27 & 0.21 & 38.1 & 33.6 \\
\hline Fine to coarse sand (3)-3 & 5.0 & 20.0 & 22.4 & 0.31 & 0.27 & $8.55 e-4$ & $1.70 e-5$ & 0.25 & 0.22 & 13.5 & 12.2 \\
\hline Sandy clay and silt (4)-3 & 4.0 & 17.9 & 20.0 & 0.55 & 0.5 & $3.48 e-7$ & $1.74 e-7$ & 0.30 & 0.21 & 38.0 & 33.3 \\
\hline Fine sand (5)-2 & 10.0 & 20.5 & 22.9 & 0.26 & 0.22 & $4.61 e-3$ & $1.70 e-5$ & 0.28 & 0.23 & 13.5 & 12.2 \\
\hline Fine to coarse sand (6)-2 & 2.5 & 19.5 & 21.8 & 0.32 & 0.28 & $3.31 e-2$ & $1.70 e-5$ & 0.23 & 0.23 & 10.2 & 9.2 \\
\hline Silty clay (7)-1 & 11.5 & 18.0 & 20.2 & 0.66 & 0.59 & $6.96 e-7$ & $3.48 e-7$ & 0.23 & 0.21 & 33.0 & 26.4 \\
\hline
\end{tabular}

Note. B represents soil parameters before grouting; A represents soil parameters after grouting.

Table 5: Thermo-physical properties and frost heave ratio of soil strata.

\begin{tabular}{|c|c|c|c|c|c|c|c|c|c|}
\hline \multirow[t]{2}{*}{ Soil stratum } & \multicolumn{2}{|c|}{$\begin{array}{l}\text { Specific heat } \\
\left(\mathrm{J} \cdot(\mathrm{kg} \cdot \mathrm{K})^{-1}\right)\end{array}$} & \multicolumn{5}{|c|}{ Thermal conductivity $\left(\mathrm{W} \cdot(\mathrm{m} \cdot \mathrm{K})^{-1}\right)$} & \multicolumn{2}{|c|}{$\begin{array}{c}\text { Frost heave } \\
\text { ratio }(\%)\end{array}$} \\
\hline & B & $\mathrm{A}$ & $-20^{\circ} \mathrm{C}$ & $-10^{\circ} \mathrm{C}$ & $-0.5^{\circ} \mathrm{C}$ & $10^{\circ} \mathrm{C}$ & $20^{\circ} \mathrm{C}$ & B & A \\
\hline Fill & 1420 & 1360 & 2.292 & 1.974 & 1.765 & 1.633 & 1.295 & 6.63 & 5.46 \\
\hline Clay and silt (3)-1 & 1410 & 1340 & 2.248 & 2.053 & 1.795 & 1.421 & 1.245 & 6.59 & 5.23 \\
\hline Fine to coarse sand (3)-3 & 1400 & 1330 & 2.245 & 2.049 & 1.763 & 1.413 & 1.224 & 4.25 & 3.53 \\
\hline Sandy clay and silt (4)-3 & 1510 & 1450 & 2.391 & 2.011 & 1.885 & 1.734 & 1.409 & 6.32 & 5.02 \\
\hline Fine sand (5)-2 & 1420 & 1360 & 2.358 & 2.073 & 2.008 & 1.748 & 1.479 & 4.13 & 3.61 \\
\hline Fine to coarse sand (6)-2 & 1430 & 1360 & 2.338 & 2.051 & 1.878 & 1.681 & 1.375 & 3.82 & 2.88 \\
\hline Silty clay (7)-1 & 1580 & 1470 & 2.371 & 2.091 & 1.896 & 1.684 & 1.541 & 5.36 & 4.37 \\
\hline
\end{tabular}

Note. B represents soil parameters before grouting; A represents soil parameters after grouting.

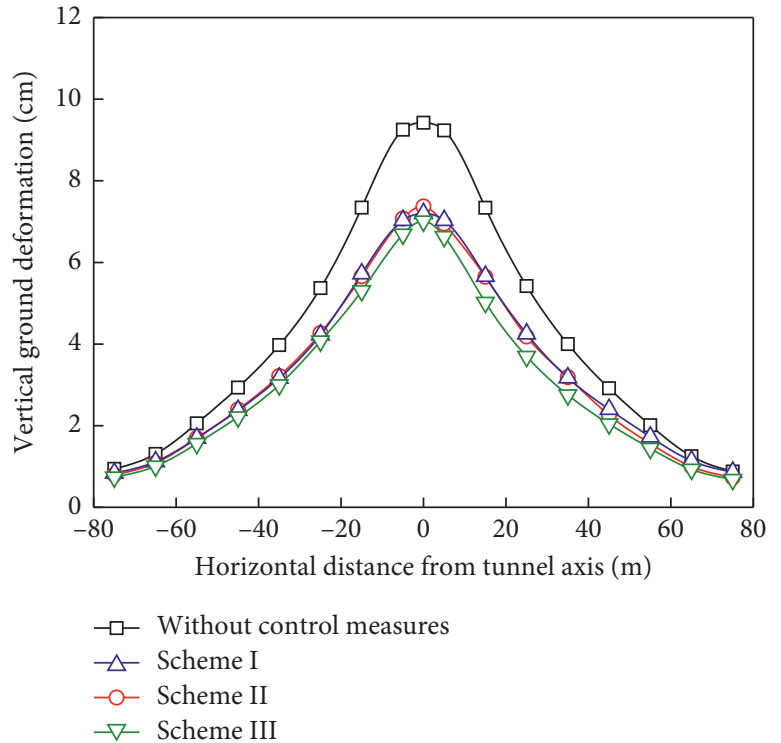

(a)

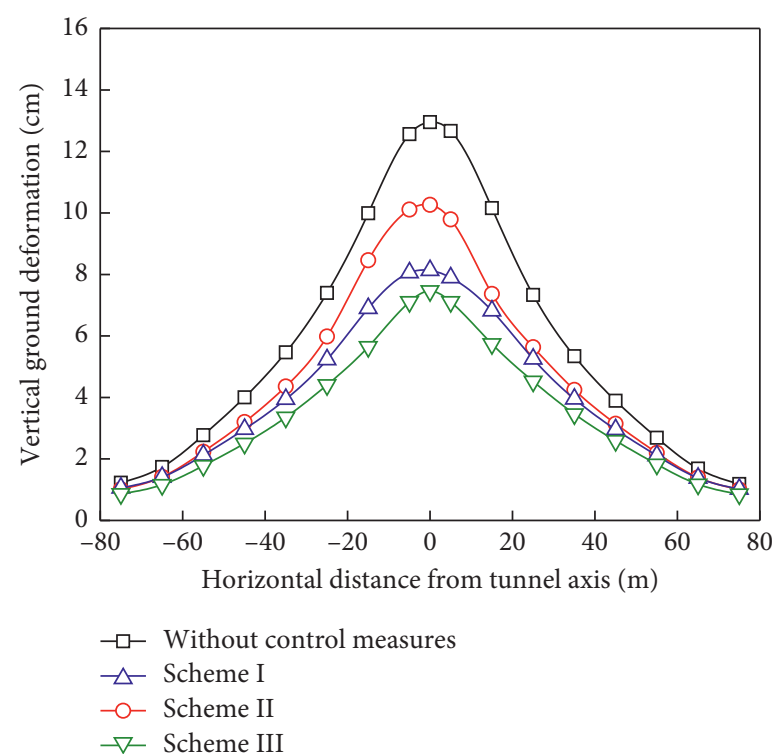

(b)

FIgURE 14: Continued. 


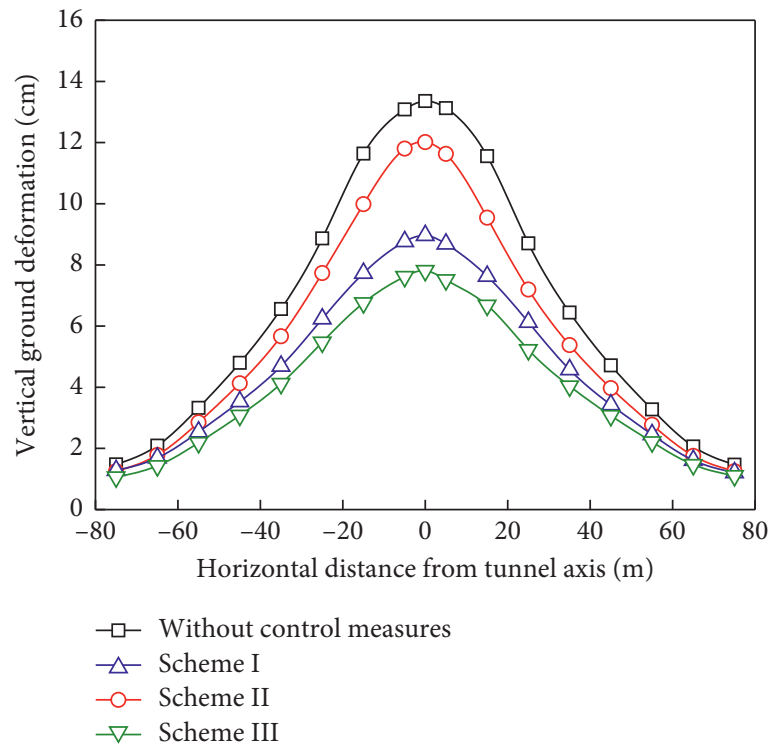

(c)

Figure 14: Vertical ground deformation of three schemes. (a) Freezing for $30 \mathrm{~d}$. (b) Freezing for $50 \mathrm{~d}$. (c) Freezing for $70 \mathrm{~d}$.

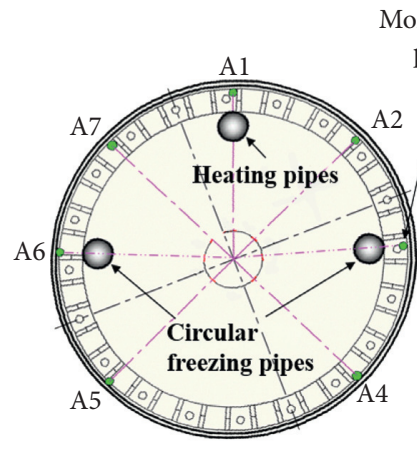

Odd-numbered roof pipe
Monitoring

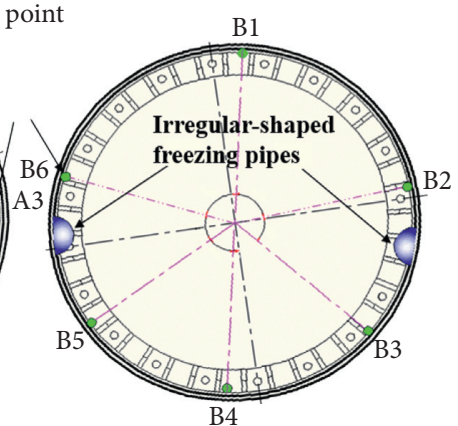

Even-numbered roof pipe

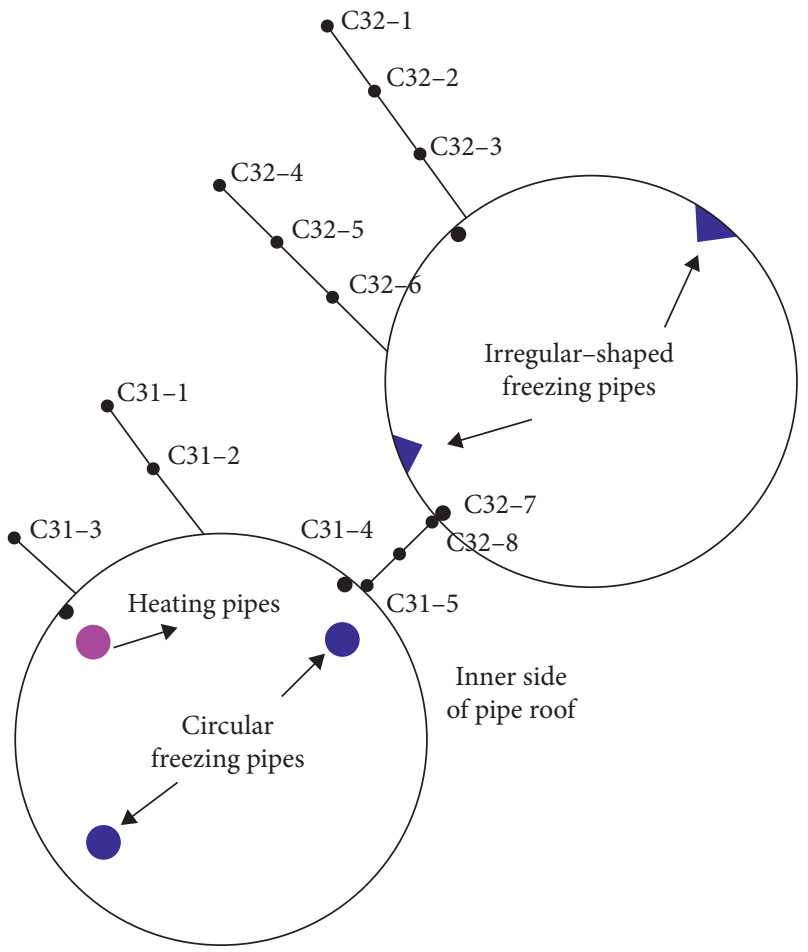

(b)

(a)

FIGURE 15: Layout of temperature monitoring points. (a) Monitoring points at the inner wall of roof pipes. (b) Monitoring points in the soil.

migration in the soil and reducing the segregation frost heave. Limiting the frozen soil thickness using heating pipes serves a supplement to the heave control. The combination of pregrouting and heating pipes has a better control effect than any single measure.
4.3. Field Measurement Analysis. The field temperature realtime monitoring system contains total of 32 monitoring sections along the $255 \mathrm{~m}$ length tunnel alignment. Figure 15 shows the layout of temperature monitoring points of each monitoring section. There are 7 monitoring points A1-A7 at 


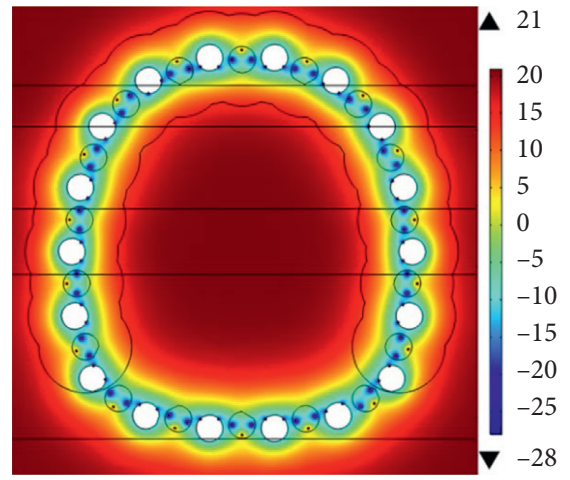

Numerical simulation

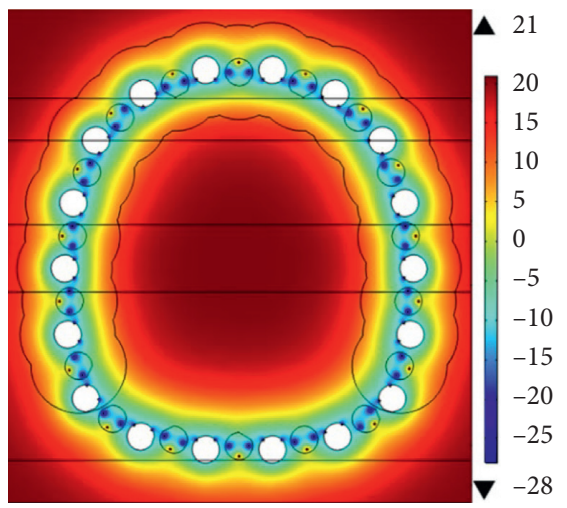

Numerical simulation

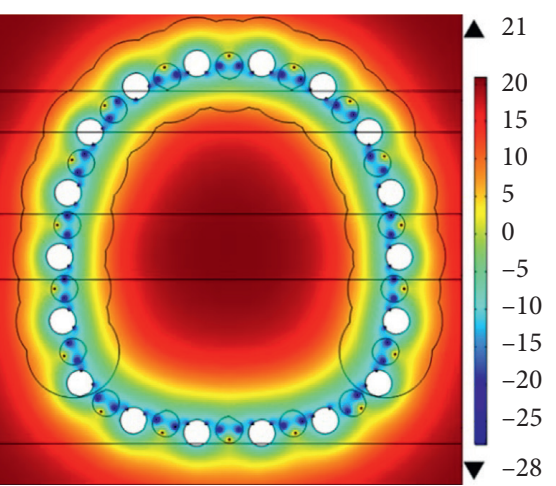

Numerical simulation

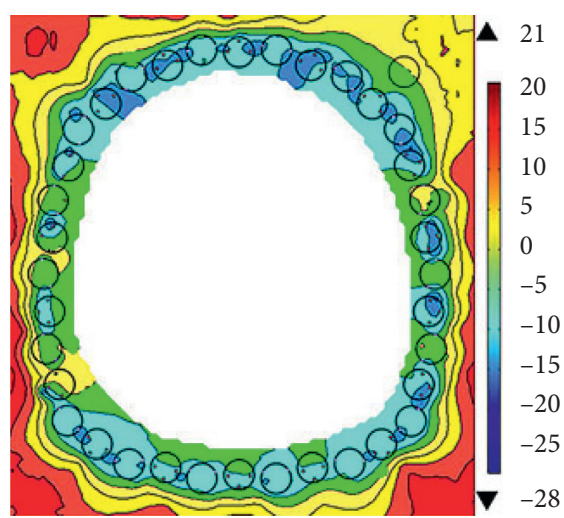

Field measurement

(a)

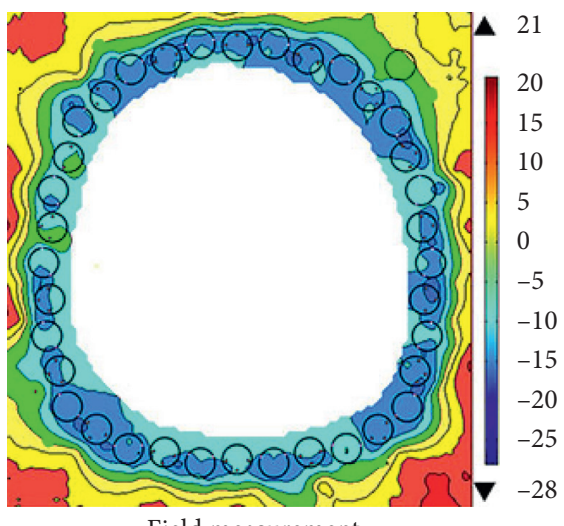

Field measurement

(b)

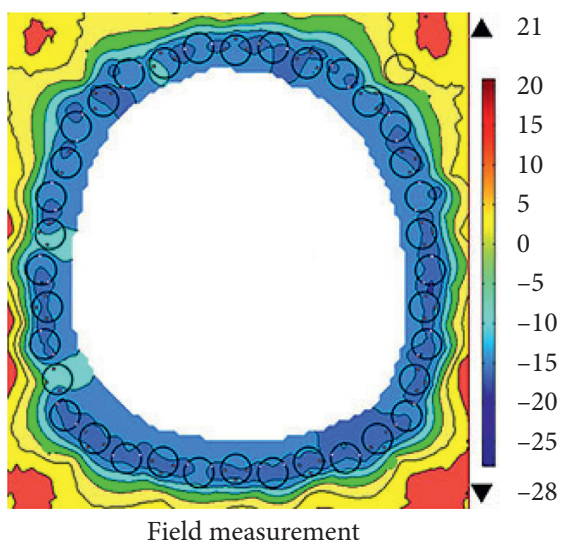

(c)

FIgURE 16: Simulation results and field measurement of frozen soil temperature (unit: ${ }^{\circ} \mathrm{C}$ ). (a) Freezing for $30 \mathrm{~d}$. (b) Freezing for $50 \mathrm{~d}$. (c) Freezing for $70 \mathrm{~d}$.

the inner wall of odd number roof pipes and 6 monitoring points $\mathrm{B} 1-\mathrm{B} 6$ at the inner wall of even number roof pipes in each monitoring section. Additionally, monitoring points are also installed in the soils around the pipe roof to collect the soil temperature.

The monitoring section CJ21 is selected to analyze the temperature development during freezing. As shown in Figure 16, the simulation results match the field measurement well, and the frozen soil develops with the time. After freezing of $70 \mathrm{~d}$, the temperature of the soil above and beneath the tunnel is around $-5^{\circ} \mathrm{C}$ and $-8^{\circ} \mathrm{C}$, respectively. The frozen soil near freezing pipes develops well with the lowest soil temperature of $-28^{\circ} \mathrm{C}$. Near the heating pipes, the soil temperature is higher and the isotherm is denser due to the circulation of hot brine. The increase in the temperature of the soil near heating pipes breaks the balance of soil temperature field, relieves the development of frozen soil, and reduces the frost heave. Since the soil around pipes 14\#-21\# 


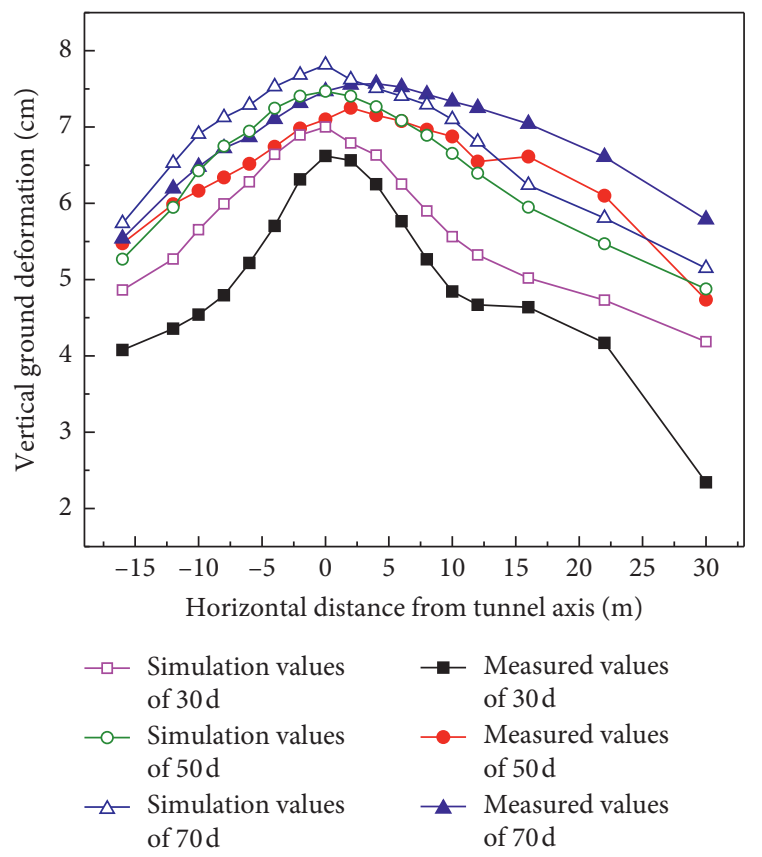

FIGURE 17: Numerical simulation and field measurement of ground heave.

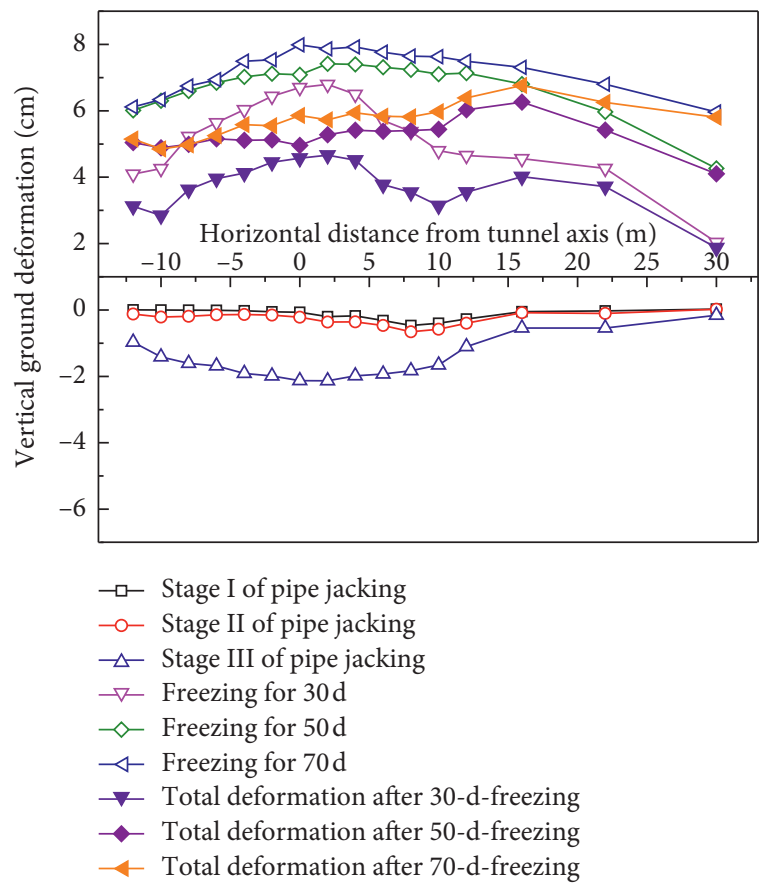

Figure 18: Vertical ground deformation of section CJ21.

was not grouted, the frozen soil at the bottom of pipe roof develops rapidly and the frozen area is larger.

Figure 17 shows the comparison of ground heave between numerical simulation and field measurement of section CJ21. In general, the numerical simulation results are consistent with those of field measurement. The simulation results of the maximum heave after freezing of 30,50 , and $70 \mathrm{~d}$ are, respectively, $7.0,7.5$, and $7.8 \mathrm{~cm}$, respectively, compared with of $6.6,7.3$, and $7.6 \mathrm{~cm}$ from the field measurement.

\section{Total Vertical Ground Deformation}

Figure 18 shows the total vertical ground deformation during the pipe roof installation and ground freezing. This figure shows that the maximum ground settlement and heave occur above the tunnel axis and the ground settlement and heave decrease with the distance from the axis. The maximum ground settlement and heave are around $2.2 \mathrm{~cm}$ and $7.8 \mathrm{~cm}$, respectively. The total vertical ground deformation is calculated by the sum of ground settlement and heave. After part of the ground heave is offset by the ground settlement, the ground surface is heaved up by an average of $3.7,5.2$, and $5.6 \mathrm{~cm}$, respectively, after freezing 30,50 , and $70 \mathrm{~d}$.

\section{Conclusions}

This paper analyzes the vertical ground movement during large-scale pipe roof installation and artificial ground freezing of Gongbei tunnel of the Hong Kong-ZhuhaiMacau bridge project. The ground settlement during pipe roof installation and the ground heave during artificial ground freezing are analyzed analytically and numerically and are compared with the field measurements. Findings from the study are:

(1) The ground settlement during pipe roof installation is relatively small. The maximum ground settlement during single pipe jacking ranges from 0.2 to $2.7 \mathrm{~mm}$ dependent on the pipe burial depth. The maximum cumulative ground settlement after jacking 37 pieces of $1620 \mathrm{~mm}$ steel pipes is $2.2 \mathrm{~cm}$.

(2) The ground settlement during pipe jacking is in an approximately parabola distribution in horizontal direction. The width coefficient of settlement trough during single pipe jacking ranges from 3.4 to $15.4 \mathrm{~m}$. The width parameter ranges from 0.31 to 0.87 and decreases with the increase of pipe burial depth. The initial ground loss ratio during pipe jacking is $1.5 \%$. Due to the reinforcement on the ground provided by the fore-jacked pipes, the average ground loss ratio at the end of all 37 pipe jacking is close to $0.8 \%$.

(3) The artificial ground freezing generates a relatively large ground heave with a maximum value of $7.8 \mathrm{~cm}$. Pregrouting plays a critical role in the frost heave control by reducing the heave by about $33 \%$. Limiting the frozen soil thickness by heating pipes serves as an effective supplement to frost heave control by reducing the heave by about $9 \%$. The combination of the two measures reduces the ground heave by about $42 \%$.

\section{Data Availability}

The data used to support the findings of this study are included within the article. 


\section{Conflicts of Interest}

The authors declare that there are no conflicts of interest regarding the publication of this paper.

\section{Acknowledgments}

The research was supported by the National Nature Science Foundation of China (NSF, Grant no. 51778386). Special thanks are extended to the NSF of China for the financial support.

\section{References}

[1] P. X. Shi, W. Liu, J. L. Pan, and C. C. Yu, "Experimental and analytical study of jacking load during micro-tunnelling Gongbei tunnel pipe roof," ASCE Journal of Geotechnical and Geoenvironmental Engineering, vol. 144, no. 1, Article ID 05017006, 2018.

[2] A. Toshikazu and O. Takashi, "Construction of large cross section tunnels in urban areas," in Proceedings of the International Congress on Progress and Innovation in Tunnelling, vol. 1, pp. 195-202, Toronto Canada, September 1989.

[3] R. N. Hunter, "The Channel tunnel, Part 3: French section," Tunnelling, vol. 231, pp. 3-14, 1994.

[4] R. B. Peck, "Deep excavations and tunnelling in soft ground," in Proceedings of the 7th International Conference on SMFE, pp. 225-290, Mexico: Balkema, 1969.

[5] C. González and C. Sagaseta, "Patterns of soil deformations around tunnels. Application to the extension of Madrid Metro," Computers and Geotechnics, vol. 28, no. 6-7, pp. $445-468,2001$.

[6] C. Oteo and J. F. Moya, "Evaluación de parámetros del suelode madrid con relación a la construcción de tuneles," in Proceedings of the 7th European Conference on Soil Mechanics and Foundation Engineering, vol. 13, pp. 239-247, Brighton, England, September 1979.

[7] K. M. Lee and R. K. Rowe, "Subsidence due to tunnelling: part II. evaluation of a prediction technique," Canadian Geotechnical Journal, vol. 31, pp. 941-954, 1992.

[8] P. B. Attewell, "Ground movements caused by tunnelling in soil," in Proceedings of the Conference on Large Ground Movements and Structures, pp. 812-948, Pentech Press, Cardiff, London, January 1978.

[9] R. J. Mair, R. N. Taylor, and A. Bracegirdle, "Subsurface settlement profiles above tunnels in clays," Géotechnique, vol. 45, no. 2, pp. 361-362, 1995.

[10] M. P. O’Reilly and B. M. New, "Settlements above tunnels in the United Kingdom: their magnitude and prediction," in Proceedings of Tunnellings'82 Symposium, pp. 173-181, Institution of Mining and Metallurgy, Brighton, London, June 1982.

[11] C. H. Zhu and N. Li, "Estimation method and laws analysis of surface settlement due to tunnelling," Rock and Soil Mechanics, vol. 37, pp. 533-542, 2016.

[12] J. H. Atkinson, D. M. Potts, and A. Schofield, "Centrifugal model tests on shallow tunnels in sand," Tunnels and Tunneling,vol. 25, pp. 705-712, 1977.

[13] E. J. Cording and W. H. Hansmire, "Displacement around soft ground tunnels, general report: session IV, tunnels in soil," in Proceedings of the 5th Panamerican Congress on Soil Mechanics and Foundation Engineering, pp. 571-632, Buenos Aires, Argentina, November 1975.
[14] N. Loganathan and H. G. Poulos, "Analytical prediction for tunneling-induced ground movements in clays," Journal of Geotechnical and Geoenvironmental Engineering, vol. 124, no. 9, pp. 846-856, 1998.

[15] P. B. Attewell, J. Yeates, and A. R. Selby, Soil Movements Induced by Tunnelling and Their Effects on Pipelines and Structures, Blackie \& Son, London, England, 1986.

[16] J. B. Burland, J. R. Standing, and F. M. Jardine, "Assessing the risk of building due to tunnelling-lessons from the jubilee line extension, London," Geotechnical Engineering: Meeting Society Needs, in Proceedings of the 14th Southeast Asian Geotechnical Conf, pp. 17-44, Hong Kong, December 2001.

[17] L. Bronfenbrener and R. Bronfenbrener, "Modeling frost heave in freezing soils," Cold Regions Science and Technology, vol. 61, pp. 0-64, 2010.

[18] R. L. Harlan, "Analysis of coupled heat-fluid transport in partially frozen soil," Water Resources Research, vol. 9, no. 5, pp. 1314-1323, 1973.

[19] Y. Lai, W. Pei, M. Zhang, and J. Zhou, "Study on theory model of hydro-thermal-mechanical interaction process in saturated freezing silty soil," International Journal of Heat and Mass Transfer, vol. 78, pp. 805-819, 2014.

[20] M. Y. Zhang, X. Y. Zhang, S. Y. Li, and J. G. Lu, "Effect of temperature gradients on the frost heave of a saturated silty clay with a water supply," Journal of Cold Regions Engineering, vol. 31, Article ID 04017011, 2017.

[21] X. D. Hu, "Laboratory research on properties of frost heave and thaw settlement of cement-improved Shanghai's greyyellow sand," Journal of China Coal Society, vol. 34, pp. 334-339, 2009.

[22] R. J. Mair, "Settlement effects of bored tunnels," in Proceedings of the International Symposium on Geotechnical Aspects of Underground Construction in Soft Ground, pp. 43-53, London: Balkema, April 1996.

[23] J. H. Liu and X. Y. Hou, Shield Tunnel, China Railway Publishing House, Beijing, China, 1991.

[24] P. X. Shi, D. L. Zhang, J. L. Pan, and W. Liu, "Geological investigation and tunnel excavation aspects of the weakness zones of Xiang'an subsea tunnels in China," Rock Mechanics and Rock Engineering, vol. 49, no. 12, pp. 4583-4867, 2016.

[25] P. Shi and P. Li, "Mechanism of soft ground tunnel defect generation and functional degradation," Tunnelling and Underground Space Technology, vol. 50, pp. 334-344, 2015. 